\title{
ANALISIS KEMAMPUAN LITERASI MATEMATIS SISWA DITINJAU DARI KARAKTER KEMANDIRIAN BELAJAR MATERI ALJABAR
}

\author{
Rizqi Kholifasari ${ }^{1}$, Citra Utami ${ }^{2}$, Mariyam ${ }^{3}$ \\ ${ }^{1}$ Program Studi Pendidikan Matematika, STKIP Singkawang \\ email: ${ }^{\text {rizqikholifasariayu@gmail.com }}$ \\ 2citrautami1990@gmail.com \\ 3.
}

\begin{abstract}
Abstrak
Penelitian ini bertujuan untuk: 1) mendeskripsikan kemampuan literasi matematis siswa pada materi aljabar ditinjau dari kemandirian belajar. 2) mendeskripsikan faktor yang mempengaruhi kemampuan literasi matematis siswa pada materi aljabar ditinjau dari kemandirian belajar. Metode penelitian ini adalah kualitatif. Subjek dalam penelitian ini adalah siswa kelas VIII-A di SMP Negeri 1 Singkawang. Instrumen pengumpulan data menggunakan angket kemandirian belajar, tes kemampuan literasi matematis, dan lembar wawancara. Teknik analisis data menggunakan Model Miles dan Huberman yaitu, reduksi data, penyajian data, dan penarikan kesimpulan. Hasil penelitian menunjukkan bahwa 1) Kemampuan literasi matematis siswa ditinjau dari karakter kemandirian belajar tinggi mempunyai rata-rata sebesar 69,44 (kategori tinggi) sebagian besar siswa tidak mampu pada tahap reasoning and argument. 2) kemampuan literasi matematis siswa ditinjau dari karakter kemandirian belajar sedang mempunyai rata-rata sebesar 57,41 (kategori sedang) sebagian besar tidak mampu pada tahap devising strategi for solving problems. 3) kemampuan literasi matematis siswa ditinjau dari karakter kemandirian belajar rendah mempunyai ratarata sebesar 46,11 (kategori sedang) sebagian besar tidak mampu pada tahap mathemathising. 4) faktor yang mempengaruhi kemampuan literasi matematis ditinjau dari karakter kemandirian belajar pada materi aljabar secara umum dipengaruhi oleh faktor internal yaitu faktor dari siswa itu sendiri, yaitu kurang mampu memahami, menerima, maupun mencerna materi pelajaran, siswa kesulitan dalam merencanakan strategi dalam pemecahan masalah baik dalam menggunakan rumus yang akan digunakan, aturan dalam pengoperasian, tidak memberikan langkah-langkah yang tepat dalam menjawab soal.
\end{abstract}

Kata kunci: kemampuan literasi matematika, kemandirian belajar.

\begin{abstract}
This study aims to: 1) describe students' mathematical literacy skills in algebraic material in terms of learning independence. 2) to describe the factors that affect students' mathematical literacy skills in algebraic material in terms of learning independence. This research method is qualitative. The subjects in this study were students of class VIII-A at SMP Negeri 1 Singkawang. The data collection instruments used a learning independence questionnaire, a mathematical literacy test, and an interview sheet. Data analysis techniques used the Miles and Huberman Model, namely, data reduction, data presentation, and drawing conclusions. The results showed that 1) The students' mathematical literacy ability in terms of their high learning independence character had an average of 69.44 (high category). Most of the students were unable to do the reasoning and argumentation stages. 2) The students' mathematical literacy skills in terms of their moderate learning independence character had an average of 57.41 (moderate category). Most of them were unable to develop strategies for solving problems. 3) The students' mathematical literacy ability in terms of their low learning independence character has an average of 46.11 (moderate category). Most of them are not capable at the mathemathising stage. 4) factors that affect mathematical literacy skills in terms of the character of independent learning in algebra material are generally influenced by internal factors, namely factors from the students themselves, students are less able to understand, accept, or digest subject matter, students have difficulty planning strategies in problem solving both in using the formula to be used, the rules in operation, do not provide the right steps in answering the questions.
\end{abstract}

Keywords: mathematical literacy skills, learning independence 
Rizqi Kholifasari ${ }^{1}$, Citra Utami $^{2}$, Mariyam ${ }^{3}$

\section{PENDAHULUAN}

Matematika adalah salah satu mata pelajaran yang dipelajari disetiap jenjang pendidikan dari jenjang sekolah dasar hingga perguruan tinggi. Matematika di sekolah mempunyai peranan yang penting untuk memecahkan masalah baik dalam mata pelajaran lain, dalam dunia kerja, maupun di kehidupan sehari-hari.

Tujuan pembelajaran matematika yang ditetapkan Permendikbud Nomor 81 A Tahun 2013 Lampiran IV menyatakan bahwa proses pembelajaran menggunakan pendekatan saintifik atau ilmiah terdiri atas lima pengalaman belajar pokok yang meliputi mengamati, menanya, mengumpulkan informasi, mengasosiasi, dan mengkomunikasikan. Sejalan dengan National Council of Mathematics (NCTM, 2000) yang menetapkan lima kompetensi dalam pembelajaran matematika: pemecahan masalah matematis (mathematical problem solving), komunikasi matematis (mathematical communication), penalaran matematis (mathematical reasoning), koneksi matematis (mathematical connection), dan representasi matematis (mathematical representation). Kelima kompetensi tersebut sangat diperlukan untuk kehidupan pembelajaran siswa sehingga menjadi warga negara yang bermanfaat agar dapat mempergunakan ilmu matematika dalam kehidupan sehari-hari. Kemampuan yang mencakup kelima kompetensi adalah kemampuan literasi matematis (Prabawati, 2018). Kemampuan literasi matematis merupakan kemampuan yang harus dikembangkan dalam pembelajaran matematika, karena jika siswa memiliki kemampuan literasi matematis memungkinkan siswa untuk memecahkan masalah dalam kehidupan sehari-hari dengan akurat dan efisien. (Haara, Bolstad, \& Jenssen, 2017) mendefinisikan literasi matematis sebagai kapasitas individu untuk merumuskan, menggunakan dan menafsirkan matematika.

Menurut Organisation for Economic Co-operation and Development (OECD, 2018) kemampuan literasi memiliki tiga domain utama yaitu (1) domain konten yang terdiri dari quantity, space and shape, change and relationship, dan uncertainty; (2) domain konteks terdiri dari personal, occuptional, societal, dan scientific, dan (3) domain proses terdiri dari merumuskan situasi secara matematis, menerapkan konsep, fakta, prosedur dan penalaran matematika, dan menginterpretasikan menggunakan dan mengevaluasi hasil matematika. Di dalam domain proses tersebut terdapat tujuh kemampuan yaitu communication, mathematising, representation, reasoning and argument, devising strategis for solving problems, using symbolyc, formal and technical language and operation, using mathematics tools. Jika siswa mampu menguasai 3 domain tersebut maka dapat dikatakan kemampuan literasi matematis siswa baik.

Dilihat dari ketujuh komponen tersebut dapat di simpulkan bahwa kemampuan literasi matematis merupakan hal yang sangat penting dalam pembelajaran matematika disebabkan karena dalam kehidupan sehari-hari manusia memang tidak pernah lepas dari kemampuan seseorang untuk memecahkan masalah secara matematis. Hal inilah yang menghubungkan matematika yang dipelajari siswa di ruang kelas dengan matematika yang ada di dunia nyata.

Namun pentingnya kemampuan literasi matematis tersebut tidak sejalan dengan prestasi Indonesia di mata internasional. Berdasarkan hasil PISA 2015, Indonesia masuk dalam 10 negara dengan kemampuan literasi rendah dengan hanya menduduki posisi 69 dari 76 negara yang disurvei oleh PISA (OECD, 2016). Rata-rata skor siswa Indonesia untuk kemampuan literasi matematis adalah 375 (level 1) sedangkan rata-rata skor internasional adalah 500 (level 3). Level 1 adalah level terendah dari 6 level kemampuan literasi matematis yang diterapkan PISA (Syawahid, 2017). Hal yang sama juga terjadi pada penelitian (Hasnawati, 2016) yang menyatakan bahwa kemampuan literasi matematis siswa masih rendah dikarenakan kurangnya kemampuan dasar matematika siswa.

Faktanya, di SMP Negeri 1 Singkawang sebagian besar siswa mengalami kesulitan dalam mengerjakan soal cerita yang berkaitan dengan kehidupan sehari-hari. Siswa masih banyak melakukan kesalahan dalam menjawab soal. Hal ini terjadi karena siswa terbiasa dengan soal yang sudah guru jelaskan sehingga siswa kesulitan jika guru memberikan soal yang berbeda 
dengan contoh. Siswa sulit menganalisa masalah dalam soal dan membuat siswa malas untuk mengerjakannya. Akibatnya siswa kurang mengasah kemampuan berfikir dan penalarannya untuk menganalisa masalah dalam soal tersebut dan soal tidak dikerjakan. Padahal kemampuan penalaran atau dari 7 komponen proses diketahui dengan istilah reasoning termasuk salah satu komponen penting dalam proses kemampuan literasi matematis. Menurut Mariyam dan Wahyuni (2016) Apabila kemampuan penalaran tidak dikembangkan pada siswa, maka bagi siswa matematika hanya akan menjadi materi yang mengikuti serangkaian prosedur dan meniru contoh tanpa mengetahui maknanya, hal yang demikian menjadikan matematika sebagai suatu hal yang monoton, terurut dan bersifat prosedural.

Hasil wawancara dengan salah satu guru di SMP Negeri 1 Singkawang diketahui bahwa sebagian besar siswa masih sulit untuk memecahkan masalah berbentuk cerita yang berkaitan dengan kehidupan sehari-hari. Sebagian besar siswa tidak dapat mengidentifikasi soal dan siswa tidak dapat mengubah soal cerita ke dalam bentuk matematika. Bahkan untuk menuliskan apa saja yang di ketahui dalam soal, sebagian siswa ada yang tidak dapat menuliskannya dikarenakan siswa masih kesulitan untuk menganalisa soal cerita yang konteksnya berkaitan dengan kehidupan sehari-hari terutama pada materi aljabar.

Salah satu materi yang paling banyak digunakan dalam kehidupan sehari-hari adalah materi Aljabar. Materi Aljabar merupakan materi yang berkaitan dengan simbol dan soal-soal cerita yang berkaitan dengan kehidupan sehari-hari. Salah satu tujuan mempelajari materi Aljabar adalah agar siswa dapat memecahkan masalah secara akurat dan efisien. hal ini berarti materi aljabar harus benar-benar dipahami oleh siswa agar mereka mampu dan terampil dalam mengaplikasikan/memanfaatkan dalam kehidupan sehari-hari.

Rendahnya kemampuan literasi matematis selain disebabkan karena jarangnya penggunaan soal yang mengacu pada kemampuan literasi, juga dikarenakan kemandirian belajar siswa yang rendah dalam pembelajaran. Selain itu (Babys, 2016) menyebutkan bahwa kemampuan literasi matematis siswa di Indonesia masih rendah. Hal ini dikarenakan kurangnya kemandirian siswa dalam belajar di kelas dan pembelajaran yang dilakukan masih berpusat pada guru, sehingga siswa pasif dan hanya menerima informasi dari guru. Menurut (Fitriana, 2010) Kemandirian belajar atau self-regulated learning diperlukan agar siswa mempunyai tanggung jawab dalam mengatur dan mendisiplinkan dirinya, selain itu dalam mengembangkan kemampuan belajar atas kemauan sendiri. Kemandirian berperan penting terhadap kemampuan literasi matematis siswa, jika siswa yang memiliki kemandirian dalam belajarnya maka siswa mampu untuk menyelesaikan pemecahan masalah dengan baik dalam proses belajarnya dan akan berpengaruh terhadap hasil belajarnya. Hal ini sejalan dengan pendapat (Darma, Firdaus, \& Haryadi, 2016) yang mengatakan bila semakin tinggi kemandirian belajar seseorang, maka akan semakin tinggi pula kemampuan pemecahan masalahnya. Akibat dari tingginya kemampuan pemecahan masalah matematis siswa akan berdampak pada prestasi ataupun hasil belajarnya. Dengan hal ini kemandirian belajar penting untuk dimiliki seorang siswa.

Kemandirian belajar menunjukkan kesiapan seorang siswa dalam menentukan mampu atau tidaknya seorang siswa dalam menentukan strategi belajarnya. Adapun karakteristik kemandirian belajar agar siswa memperoleh hasil belajar yang lebih baik. Menurut Sumarmo (2010) memaparkan ada tiga karakteristik kemandirian belajar, (1) individu merancang belajarnya sendiri sesuai dengan keperluan atau tujuan individu yang bersangkutan; (2) individu memilih strategi dan melaksanakan rancangan belajarnya; (3) individu memantau kemajuan belajarnya sendiri, mengevaluasi hasil belajarnya dan dibandingkan dengan standar tertentu. Ketika seorang siswa memiliki kemandirian dalam belajarnya siswa tersebut akan dapat dengan mudah mendapatkan pengetahuan yang lebih luas tanpa ada batasan, serta dapat mengetahui sejauh mana kemampuan dirinya dalam belajar, dan siswa dapat mengevaluasi diri dalam belajarnya agar terus menjadi lebih baik. Dengan demikian diperlukan adanya kemandirian siswa dalam belajarnya. Hal ini dikarenakan kemandirian belajar berpengaruh terhadap hasil belajar yang mereka peroleh. Oleh karena itu, tujuan penelitian ini untuk mendeskripsikan kemampuan literasi matematis siswa pada materi aljabar untuk siswa yang memiliki karakter 
Rizqi Kholifasari ${ }^{1}$, Citra Utami $^{2}$, Mariyam ${ }^{3}$

kemandirian belajar tinggi, sedang, rendah. faktor yang mempengaruhi kemampuan literasi matematis siswa pada materi aljabar ditinjau dari karakter kemandirian belajar siswa kelas VIII di SMP Negeri 1 Singkawang.

\section{METODE PENELITIAN}

Jenis penelitian ini adalah jenis penelitian kualitatif dengan metode deskriptif. Adapun sekolah yang menjadi tempat penelitian adalah SMP Negeri 1 Singkawang kelas VIII. Subjek dalam penelitian ini adalah seluruh kelas VIIIA SMP Negeri 1 Singkawang yang berjumlah 30 siswa. Teknik pengambilan sampel pada penelitian ini dengan menggunakan teknik purposive sampling. Berdasarkan hasil pengamatan bahwa instrumen dalam penelitian ini telah di validasi oleh beberapa ahli sehingga di peroleh hasil valid dan sangat valid, soal dan angket juga sudah dilakukan uji coba dan memperoleh hasil bahwa soal dapat digunakan untuk penelitian ini.

Teknik analisis data yang digunakan dalam penelitian ini adalah teknik analisis interaktif yang dikembangkan oleh Miles dan Huberman (Sugiyono, 2017) yaitu reduksi data (data reduction), penyajian data (data display) dan penarikan kesimpulan (verification). Dalam penelitian ini akan diperoleh data secara kuantitatif sehingga untuk menganalisis data didapatkan dari pemberian tes kemampuan literassi matematis, angket kemandirian belajar dan wawancara kepada 7 siswa sebagai subjek wawancara terkait hasil tes yang dikerjakannya.

\section{HASIL DAN PEMBAHASAN}

Bagian ini berisi pembahasan hasil penelitian berupa deskripsi kemampuan literasi matematis siswa (tinggi, sedang, rendah) ditinjau dari kemandirian belajar (tinggi, sedang dan rendah) dan faktor yang mempengaruhi yang berpandu pada indikator kemampuan literasi matematis. Pada tiap soal memuat indikator kemampuan literasi matematis:

\section{Kemampuan Literasi Matematis Siswa Ditinjau Dari Karakter Kemandirian Belajar Tinggi}

Hasil pengumpulan data selama penelitian diperoleh 3 siswa yang memiliki kemandirian belajar tinggi dengan rata-rata nilai tes kemampuan literasi matematis sebesar 68,51. Banyaknya siswa pada tiap kategori kemampuan literasi matematis ditinjau dari kemandirian belajar tinggi dapat dilihat pada Tabel 1.

Tabel 1. Kemampuan Literasi Matematis Ditinjau Dari Kemandirian Belajar Tinggi.

\begin{tabular}{|c|c|c|c|c|c|}
\hline $\begin{array}{c}\text { Kategori } \\
\text { Angket }\end{array}$ & $\begin{array}{c}\text { Kategori } \\
\text { Tes }\end{array}$ & $\begin{array}{c}\text { Banyak } \\
\text { Siswa }\end{array}$ & $\begin{array}{c}\text { Jumlah Nilai } \\
\text { Tes }\end{array}$ & $\begin{array}{c}\text { Rata-Rata } \\
\text { Tes }\end{array}$ & $\begin{array}{c}\text { Kategori Rata- } \\
\text { Rata Tes }\end{array}$ \\
\hline \multirow{3}{*}{ Tinggi } & Tinggi & 2 & 144,44 & 72,22 & \multirow{3}{*}{ Tinggi } \\
\cline { 2 - 6 } & Sedang & 1 & 61,11 & 61,11 & \multirow{3}{*}{} \\
\cline { 2 - 6 } & Rendah & 0 & 0 & 0 & \\
\hline \multicolumn{2}{|c|}{ Total } & 3 & 205,55 & 68,52 & \\
\hline
\end{tabular}

Dari Tabel 1 terlihat bahwa kemampuan literasi matematis siswa ditinjau dari kemandirian belajar tinggi hanya berada pada kategori tinggi dan sedang dengan kategori rata-rata tes berada pada kategori tinggi.

Berdasarkan hasil penelitian pada siswa dengan yang memilki kemandirian belajar tinggi ternyata siswa hanya berada pada kategori Tinggi dan sedang. Siswa dengan memiliki kemampuan literasi tinggi ternyata bisa menyelesaikan pada indikator mampu merumuskan soal kedalam bentuk matematika dengan baik dengan siswa mampu menuliskan kembali apa saja yang diketahui dari permasalahan tersebut, dapat memodelkan soal kedalam bentuk matematika, dan dapat menyajikan soal kedalam bentuk tabel, mampu menerapkan konsep matematika, fakta, prosedur, dan penalaran dengan baik dengan siswa dapat menggunakan prosedur, langkah-langkah pengerjaannya dengan tepat, menggunakan simbol dengan baik, dapat menggunakan rumus dengan benar, dan mampu menafsirkan, menerapkan dan mengevaluasi 
hasil yang diperoleh dengan cukup baik dengan siswa dapat memberikan kesimpulan atau memberikan alasan yang logis pada permasalahan yang diberikan.

Siswa dengan kategori kemampuan literasi matematis sedang, mampu merumuskan soal kedalam bentuk matematika dengan baik dengan siswa mampu menuliskan kembali apa saja yang diketahui dari permasalahan tersebut, dapat memodelkan soal kedalam bentuk matematika, dan dapat menyajikan soal kedalam bentuk tabel, mampu menerapkan konsep matematika, fakta, prosedur, dan penalaran dengan baik dengan siswa dapat menggunakan prosedur, langkah-langkah pengerjaannya dengan tepat, menggunakan simbol dengan baik, dapat menggunakan rumus dengan benar, dan mampu menafsirkan, menerapkan dan mengevaluasi hasil yang diperoleh dengan cukup baik dengan siswa dapat memberikan kesimpulan atau memberikan alasan yang logis pada permasalahan yang diberikan meskipuan hasil masil keliru.

Berdasarkan hasil penelitian siswa dengan kemandirian belajar tinggi maka akan memiliki kemampuan literasi matematis yang tinggi. Hasil penelitian yang dilakukan oleh (Supratinah, Budiyono \& Subanti, 2015) mengatakan bahwa siswa dengan kemandirian belajar tinggi lebih baik dari pada siswa yang memiliki kemandirian belajar sedang dan rendah. Hal ini dikarenakan jika siswa memiliki kemandirian dalam belajarnya siswa mampu untuk merencanakan situasi belajar yang baik, mampu untuk mengetahui apa kelebihan dan kekurangannya dalam belajar. Hal ini sejalan dengan teori humanistik, teori ini mengatakan bahwa siswa dianggap berhasil dalam belajarnya jika siswa mampu untuk memahami dirinya dan lingkungannya sehingga dapat mengaktualisasikan diri dengan sebaik-baiknya (Lestari \& Yudhanegara, 2015).

Siswa yang mampu memiliki kemandirian belajar yang baik dalam kemampuan literasi matematisnya siswa mampu untuk menuliskan apa saja yang diketahui dalam soal, mengubah soal kedalam bentuk matematika dan menyajikan soal kedalam bentuk tabel dengan baik dan benar, siswa mampu menggunakan rumus dan menggunakan simbol dengan cukup baik. Hal ini sejalan dengan hasil penelitian (Khotimah, Utami, \& Citroresmi, 2018) mengatakan bahwa seseorang yang memiliki kemampuan literasi matematis tentu dapat memiliki kemampuan berkomunikasi. Sejalan dengan (Mahiuddin \& Pratama, 2019) menyatakan bahwa kemampuan literasi matematika siswa unggul dalam mengkomunikasikan, penggunaan simbol, bahasa formal, teknik dan penggunaan operasi.

Pada siswa yang memiliki kemandirian belajar tinggi sebagian besar siswa masih kurang dalam reasoning and argument, sebagian besar siswa belum mampu mengerjakan dengan baik, hal tersebut dikarenakan terdapat kesalahan yang diakibatkan siswa dalam setiap langkah pengerjaannya kurang teliti dalam memberikan alasan secara logis dan subjek kurang paham terhadap soal. Sejalan dengan hasil penelitian yang di lakukan oleh (Mahdiansyah \& Rahmawati, 2014) menyatakan bahwa siswa menjawab soal matematika tanpa penjelasan dan langkah kerja perhitungannya, hal ini menunjukkan siswa kurang mampu memberikan uraian atau argumentasi terhadap persoalan matematika.

\section{Kemampuan Literasi Matematis Siswa Ditinjau Dari Karakter Kemandirian Belajar Sedang.}

Hasil pengumpulan data selama penelitian diperoleh 22 siswa yang memiliki kemandirian belajar sedang dengan rata-rata nilai tes kemampuan literasi matematis sebesar 59,98. Banyaknya siswa pada tiap kategori kemampuan literasi matematis ditinjau dari kemandirian belajar sedang dapat dilihat pada Tabel 2

Tabel 2 Kemampuan Literasi Matematis Ditinjau Dari Kemandirian Belajar Sedang

\begin{tabular}{|c|c|c|c|c|c|}
\hline $\begin{array}{c}\text { Kategori } \\
\text { Angket }\end{array}$ & $\begin{array}{c}\text { Kategori } \\
\text { Tes }\end{array}$ & $\begin{array}{c}\text { Banyak } \\
\text { Siswa }\end{array}$ & $\begin{array}{c}\text { Jumlah Nilai } \\
\text { Tes }\end{array}$ & $\begin{array}{c}\text { Rata-Rata } \\
\text { Tes }\end{array}$ & $\begin{array}{c}\text { Kategori Rata- } \\
\text { Rata Tes }\end{array}$ \\
\hline \multirow{3}{*}{ Sedang } & Tinggi & 8 & 608,34 & 76,04 & \multirow{3}{*}{ Sedang } \\
\cline { 2 - 5 } & Sedang & 12 & 650 & 54,17 & \multirow{2}{*}{} \\
\cline { 2 - 6 } & Rendah & 2 & 61,12 & 30,56 & \\
\hline \multicolumn{2}{|c|}{ Total } & 22 & 1319,5 & 59,98 & \\
\hline
\end{tabular}


Rizqi Kholifasari ${ }^{1}$, Citra Utami ${ }^{2}$, Mariyam ${ }^{3}$

Dari Tabel 2 terlihat bahwa kemampuan literasi matematis siswa ditinjau dari kemandirian belajar sedang memiliki kategori tinggi, sedang, dan rendah, dengan kategori rata-rata tes berada pada kategori sedang. .

Berdasarkan hasil penelitian pada siswa yang memiliki kemandirian belajar sedang ternyata siswa hanya berada pada kategori Tinggi, sedang dan rendah. Siswa dengan memiliki kemampuan literasi tinggi ternyata mampu merumuskan soal kedalam bentuk matematika dengan baik dengan siswa mampu menuliskan kembali apa saja yang diketahui dari permasalahan tersebut, dapat memodelkan soal kedalam bentuk matematika, dan dapat menyajikan soal kedalam bentuk tabel, mampu menerapkan konsep matematika, fakta, prosedur, dan penalaran dengan baik dengan siswa dapat menggunakan prosedur, langkah-langkah pengerjaannya dengan tepat, menggunakan simbol dengan baik, dapat menggunakan rumus dengan benar, dan mampu menafsirkan, menerapkan dan mengevaluasi hasil yang diperoleh dengan cukup baik dengan siswa mampu mengevaluasi hasil yang ditemukan meskipun siswa kesulitan dalam memberikan alasan yang logis.

Siswa dengan kategori kemampuan literasi matematis sedang. Mampu merumuskan soal kedalam bentuk matematika dengan baik dengan siswa mampu menuliskan kembali apa saja yang diketahui dari permasalahan tersebut, dapat memodelkan soal. Kedalam bentuk matematika, dan dapat menyajikan soal kedalam bentuk tabel, mampu menerapkan konsep matematika fakta, prosedur, dan penalaran dengan cukup baik siswa dapat menggunakan prosedur, langkah-langkah pengerjaannya namun masih keliru, menggunakan simbol dengan baik, dapat menggunakan rumus dengan cukup baik, dan mampu menafsirkan, menerapkan dan mengevaluasi hasil yang diperoleh cukup baik dengan siswa dapat memberikan kesimpulan atau memberikan alasan yang logis pada permasalahan yang diberikan meskipun hasil masih keliru. Siswa dengan kategori kemampuan literasi matematis rendah. Mampu merumuskan soal kedalam bentuk matematika dengan cukup baik dengan siswa dapat menuliskan apa saja yang diketahui dalam soal namun tidak dapat mengubah soal kedalam bentuk matematika, siswa mampu menyajikan soal kedalam bentuk tabel, mampu menerapkan konsep matematika, fakta, prosedur, dan penalaran dengan kurang baik dikarenakan siswa masih kurang dalam penggunaan prosedur yang baik, tidak dapat merencanakan strategi pemecahan masalah, penggunaan rumus yang buruk, aturan pengoperasian yang salah, dan mampu menafsirkan, menerapkan dan mengevaluasi hasil yang diperoleh dengan kurang baik dikarenakan siswa tidak mampu untuk memberikan alasan secara logis mengenai permasalahan yang diberikan.

Hasil dari tes dan hasil wawancara pada siswa yang memiliki kemampuan literasi matematis kemandirian belajar sedang bahwa sebagian besar siswa masih kesulitan terhadap devising strategi for solving problem, dikarenakan siswa masih sulit untuk memahami soal dan merencanakan penyelesaian terhadap masalah yang diberikan seperti kesulitan dalam penggunaan rumus, penggunaan simbol, maupun masih kesulitan dalam sifat pengoperasian. Sejalan dengan hasil penelitian yang dilakukan oleh (Mahiuddin \& Pratama, 2019) yang mengatakan bahwa kemampuan literasi masih rendah pada kompetensi merencanakan strategi.

\section{Kemampuan Literasi Matematis Siswa Ditinjau Dari Karakter Kemandirian Belajar Rendah}

Hasil pengumpulan data selama penelitian diperoleh 5 siswa yang memiliki kemandirian belajar rendah dengan rata-rata nilai tes kemampuan literasi matematis sebesar 42,78. Banyaknya siswa pada tiap kategori kemampuan literasi matematis ditinjau dari kemandirian belajar rendah dapat dilihat pada Tabel 3.

Tabel 3 Kemampuan Literasi Matematis Ditinjau Dari Kemandirian Belajar Rendah

\begin{tabular}{|c|c|c|c|c|c|}
\hline $\begin{array}{c}\text { Kategori } \\
\text { Angket }\end{array}$ & $\begin{array}{c}\text { Kategori } \\
\text { Tes }\end{array}$ & $\begin{array}{c}\text { Banyak } \\
\text { Siswa } \\
\end{array}$ & $\begin{array}{c}\text { Jumlah } \\
\text { Nilai Tes }\end{array}$ & $\begin{array}{c}\text { Rata-Rata } \\
\text { Tes } \\
\end{array}$ & $\begin{array}{c}\text { Kategori Rata- } \\
\text { Rata Tes } \\
\end{array}$ \\
\hline \multirow{3}{*}{ Rendah } & Tinggi & 0 & 0 & 0 & \multirow{4}{*}{ Sedang } \\
\hline & Sedang & 3 & 152,77 & 50,92 & \\
\hline & Rendah & 2 & 61,12 & 30,56 & \\
\hline \multicolumn{2}{|c|}{ Total } & 5 & 213,89 & 42,78 & \\
\hline
\end{tabular}


Dari Tabel 3 terlihat bahwa kemampuan literasi matematis siswa ditinjau dari kemandirian belajar rendah hanya berada pada kategori sedang dan rendah dengan kategori rata-rata tes berada pada kategori sedang.

Berdasarkan hasil penelitian pada siswa dengan yang memiliki kemandirian belajar rendah ternyata siswa hanya berada pada kategori sedang dan rendah Siswa dengan memiliki kemampuan literasi sedang ternyata Mampu merumuskan soal kedalam bentuk matematika dengan siswa mampu menuliskan apa saja yang diketahui dalam soal, mengubah permasalahan kedalam model matematika maupun menyajikan permasalahan kedalam bentuk tabel dengan baik meskipun belum sepnuhnya lengkap, mampu menerapkan konsep matematika, fakta, prosedur dan penalaran dengan siswa mampu untuk menggunakan prosedur, langkah-langkah pengerjaannya dengan memperoleh hasil yang benar namun dengan langkah yang kurang lengkap, menggunakan simbol dengan baik, dapat menggunakan rumus dengan benar, dan mampu menafsirkan, menerapkan dan mengevaluasi hasil yang diperoleh dengan cukup baik dengan siswa dapat memberikan kesimpulan atau memberikan alasan yang logis pada permasalahan yang diberikan meskipun hasil masih keliru.

Siswa dengan kategori kemampuan literasi matematis rendah. Mampu merumuskan soal kedalam bentuk matematika dengan cukup baik siswa dapat menuliskan apa saja yang diketahui, dapat menyajikan soal kedalam bentuk tabel namun siswa tidak dapat mengubah soal kedalam model matematika, mampu menerapkan konsep matematika, fakta, prosedur, dan penalaran dengan cukup baik siswa dapat merencana strategi namun hasil yang digunakan keliru siswa tidak menuliskanlangkah dengan tepat, aturan pengoperasian yang keliru, penggunaan simbol yang kurang tepat, dan mampu menafsirkan, menerapkan dan mengevaluasi hasil yang diperoleh dengan kurang baik siswa tidak dapat memberikan alasan secara logis dari permasalahan yang diberikan.

Siswa yang memiliki kemandirian belajar yang baik dalam belajarnya maka akan berdampak pada kemampuan siswa tersebut, namun jika siswa memiliki kemandirian belajar yang rendah juga akan berdampak pada kemampuan siswa tersebut. Berdasarkan hasil penelitian siswa dengan kemandirian belajar rendah sebagian besar siswa masih kesulitan dalam menyelesaikan masalah yang diberikan diantaranya merumuskan situasi secara matematis pada tahap mathemathizing, dikarenakan siswa masih sulit untuk mengubah permasalahan nyata kedalam model matematika. Sejalan dengan hasil penelitian yang dilakukan oleh (Wati \& Murtiyasa, 2016) yang mengatakan bahwa kemampuan penalaran dan kreativitas siswa yang rendah dalam memecahkan masalah konteks nyata dan memanipulasinya ke dalam bentuk aljabar.

\section{Faktor Yang Mempengaruhi Kemampuan Literasi Matematis siswa Ditinjau Dari Karakter Kemandirian Belajar Siswa}

Berdasarkan hasil tes dan hasil wawancara kepada siswa yang memiliki kemandirian belajar tinggi sedang maupun rendah dalam menyelesaikan soal kemampuan literasi matematis siswa. Siswa dengan kemandirian belajar tinggi faktor yang mempengaruhi subjek antara lain tingkat pemahaman siswa terhadap materi maupun soal dan kurang teliti dikarenakan pada saat proses pembelajaran siswa tidak dapat fokus dalam menerima materi. Siswa dengan kemandirian belajar sedang faktor yang mempengaruhi antara lain tidak bisa membuat model matematika, tidak dapat memberikan kesimpulan, tidak dapat menentukan rumus, salah dalam aturan pengoperasian, langkah-langkah pengerjaan kurang lengkap dan siswa tidak dapat memberikan alasan secara logis dikarenakan tingkat pemahaman siswa terhadap materi maupun soal dan kurang teliti hal ini disebabkan pada saat proses pembelajaran siswa tidak dapat fokus dalam menerima materi, malu untuk bertanya ketika ada materi yang sulit dipahami dan memiliki inisiatif dalam belajar yang kurang baik.

Faktor yang mempengaruhi subjek pada kemandirian belajar rendah antara lain tidak bisa membuat model matematika, tidak dapat memberikan kesimpulan, tidak dapat menentukan rumus, langkah-langkah pengerjaan kurang lengkap hal ini disebabkan karena, pada saat proses pembelajaran siswa tidak dapat fokus menerima materi, siswa malu untuk bertanya ketika ada materi yang sulit dipahami dan memiliki inisiatif dalam belajar yang kurang baik. 
Rizqi Kholifasari ${ }^{1}$, Citra Utami $^{2}$, Mariyam ${ }^{3}$

Berdasarkan Pembahasan di atas dapat terlihat bahwa faktor yang mempengaruhi kemampuan literasi matematis ditinjau dari karakter kemandirian belajar antara lain siswa sulit untuk memahami soal maupun mengubah permasalahan sehari-hari pada soal tersebut ke dalam bentuk atau model matematikanya, siswa banyak tidak mengerti cara mengoperasikan bentuk aljabar, mengira semua bisa dijumlahkan dan dalam hal perkalian hanya bilangan tertentu saja yang dapat dikalikan. Kurang paham terhadap soal juga menyebabkan siswa tidak dapat merencana strategi untuk menyelesaikan masalah baik dalam hal menggunakan rumus, prosedur dengan baik, maupun, langkah pengerjaan yang kurang tepat, siswa masih kesulitan untuk mengevaluasi soal, siswa hanya memberikan alasan tanpa menyertakan langkah-langkah penemuan hasil atau penggunaan konsep yang terdapat dalam penemuan masalah terhadap soal sehingga siswa masih banyak yang keliru.

Dari hasil wawancara mengenai kemandirian disebabkan karena pada saat siswa dalam proses pembelajaran berlangsung siswa kurang fokus terhadap materi yang disampaikan, sehingga informasi yang diperoleh kurang diterima secara maksimal oleh siswa, jika siswa tidak paham siswa takut untuk menanyakan kembali materi yang tidak pahami oleh siswa, dan kurangnya kesadaran siswa untuk mengulang kembali materi yang telah di sampaikan di sekolah, sehingga membuat mereka kesulitan untuk memecahkan masalah terhadap materi yang telah lalu. Hal ini sejalan dengan hasil penelitian (Sobri \& Moerdiyanto,2014) yang mengatakan bahwa kemandirian belajar siswa tergolong rendah dikarenakan adanya siswa yang malu bertanya apabila menghadapi kesulitan memahami materi pelajaran dan siswa pasif dalam kegiatan belajar mengajar.

Hasil penelitian yang dilakukan oleh (Wati \& Murtiyasa, 2016) mengatakan bahwa secara umum faktor penyebab kesalahan adalah kemampuan penalaran dan kreativitas siswa yang rendah dalam memecahkan masalah konteks nyata dan memanipulasinya ke dalam bentuk aljabar dan siswa tidak terbiasa menggunakan proses pemecahan masalah dengan benar sesuai langkah Polya. Hasil penelitian yang dilakukan oleh (Lukman \& Zanthy, 2019) mengatakan bahwa Siswa masih keliru dalam proses penyelesaian, dalam penggunaan rumus, tidak mampu dalam menginterpretasikan soal, keliru dalam menyimpulkan hasil penyelesaian dan tidak tuntas dalam penyelesaian.

\section{KESIMPULAN}

Hasil penelitian dapat disimpulkan bahwa kemampuan literasi matematis siswa ditinjau dari karakter kemandirian belajar tinggi mempunyai rata-rata sebesar 69,44 (kategori tinggi) sebagian besar siswa tidak mampu pada tahap reasoning and argument, kemampuan literasi matematis siswa ditinjau dari karakter kemandirian belajar sedang mempunyai rata-rata sebesar 57,41 (kategori sedang) sebagian besar tidak mampu pada tahap devising strategi for solving problems, kemampuan literasi matematis siswa ditinjau dari karakter kemandirian belajar rendah mempunyai rata-rata sebesar 46,11 (kategori sedang) sebagian besar tidak mampu pada tahap mathemathizing.

Faktor yang mempengaruhi kemampuan literasi matematis ditinjau dari karakter kemandirian belajar pada materi aljabar secara umum dipengaruhi oleh faktor internal yaitu faktor dari siswa itu sendiri, siswa kurang mampu untuk memahami, menerima, maupun mencerna materi pelajaran, siswa kesulitan dalam merencanakan strategi dalam pemecahan masalah baik dalam menggunakan rumus yang akan digunakan, aturan dalam pengoperasian, tidak memberikan langkah-langkah yang tepat dalam menjawab soal.

\section{REFERENSI}

Babys, U. (2016). Kemampuan Literasi Matematis Space And Shape Dan Kemandirian Siswa SMA Pada Discovery Learning Berpendekatan RME-PISA. Jurnal Pendidikan Matematika Indonesia, 1(2), 43-49. 
Darma, Y., Firdaus, M., \& Haryadi, R. (2016). Hubungan Kemandirian Belajar Terhadap Kemampuan Pemecahan Masalah Matematis Mahasiswa Calon Guru Matematika. Jurnal Edukasi, 14(1), 169-178.

Fitriana, L. (2010). Pengaruh Moedel Pembelajaran Cooperative Tipe Group Investigation (GI) Dan STAD Terhadap Prestasi Belajar Matematika Ditinjau Dari Kemandirian Belajar Siswa.

Haara, F. O., Bolstad, O. H., \& Jenssen, E. S. (2017). Research on mathematical literacy in schools - Aim, approach and attention. European Journal of Science and Mathematics Education, 5(3), 285-313.

Hasnawati. (2016). Description Of Mathematics Literacy Ability Of Students First Secondary School State 15 Kendari Based On Content, Context, Materials, And Process. International Journal of Education and Research, 4(11), 201-210.

Khotimah, Utami, \& Citroresmi. (2018). Penerapan Model Learning Cycle 7E Untuk Meningkatkan Kemampuan Literasi Matematis Siswa Kelas VIII Pada Materi Prisma. Jurnal Pendidikan Matematika Indonesia, 3(1), 15-20.

Lestari dan Yudhanegara. (2015). Penelitian Pendidikan Matematika Bandung: PT. Refika Aditama.

Lukman, S., \& Zanthy, L. S. (2019). Analisis Kesalahan Siswa SMK Dalam Memecahkan Masalah Literasi Matematis Pada Materi Bangun Ruang. Jurnal Pembelajaran Matematika Inovatif, 2(3), 101-106.

Mahdiansyah, \& Rahmawati. (2014). Literasi Matematika Siswa Pendidikan Menengah: Analisis Menggunakan Desain Tes Internasional dengan Konteks Indonesia. Jurnal Pendidikan Dan Kebudayaan, 20(4), 452-469.

Mahiuddin, \& Pratama. (2019). Analisis Kemampuan Literasi Matematis Siswa SMP Di Kabupaten Konawe Dalam Perspektif Gender: (An Analysis Of Mathematical Literacy Ability Of SMP Kabupaten Konawe In Gender Perspective). Jurnal Pendidikan Matematika, 10(1), 55-65.

Mariyam, M \& Wahyuni R, .2016. "Mengembangkan Kemampuan Penalaran Matematis Siswa Melalui Problem Centered Learning Pada Materi Peluang (Study Eksperimen Di Kelas VIII SMP N 6 Singkawang)" dalam Jurnal Pendidikan Matematika Indonesia) Volume 1 No. 2, hal.74-80. September 2016 (Terakreditasi).

OECD. (2018). PISA for Development Assessment and Analytical Framework Reading, Mathematics And Science. Paris: OECD Publishing.

Prabawati, M. N. (2018). Analisis Kemampuan Literasi Matematik Mahasiswa Calon Guru Matematika. Jurnal Mosharafa, 7(1), 113-120.

Sobri, M., \& Moerdiyanto. (2014). Pengaruh Kedisiplinan dan Kemandirian Belajar Terhadap Hasil Belajar Ekonomi Madrasah Aliyah Di Kecamatan Praya. Jurnal Harmoni Sosial, 1(5), 43-56.

Sumarmo, Utari. 2010. "Kemandirian Belajar: Apa, Mengapa, dan Bagaimana Dikembangkan Pada Peserta Didik". Makalah/Jurnal Pendidikan Matematika.

Supratinah, Budiyono \& Subanti. (2015). Eksperimentasi Model Pembelajaran Discovery Learning, Dan Think-Talk-Write Dengan Pendekatan Saintifik Terhadap Kemampuan Pemecahan Masalah Matematika Ditinjau Dari Kemandirian Belajar. Jurnal Elektronik Pembelajaran Matematika, 3(10) 1138-1149,

Syawahid, M, \& Putrawangsa, S. (2017). Kemampuan Literasi Matematika Siswa SMP Ditinjau gaya Belajar. Jurnal Tadris Matematika, 10(2), 222-240.

Wati \& Murtiyasa. (2016). Kesalahan Siswa SMP Dalam Menyelesaikan Soal Matematika Berbasis PISA Pada Konten Change And Relationship. Prosiding Seminar Nasional Matematika,199-299. 